\title{
The South African International Co- operation in Criminal Matters Act and the issue of evidence
}

Jamil Ddamulira Mujuzi*

LLB (Hons) LLM LLM LLD

Associate Professor of Law, Faculty of Law, University of the Western Cape

\section{OPSOMMING}

Die Suid Afrikaanse Wet op Internasionale Samewerking in Strafregtelike Aangeleenthede en die Kwessie van Getuienis

Suid Afrika het verskeie inisiatrewe aangeneem ten einde tesame met ander lande misdaad te bekamp. Een sodanige inisratief behels die aanname van die Wet op Internasionale Samewerking in Strafregtelike Aangeleenthede (International Co-operation in Criminal Matters Act ('ICCMA')) in 1996, weike wet ten doel het om getuienis lewering, die uitvoering van vonnisse in strafsake, en die konfiskering en oordrog van opbrengste voortspruitend uit misdaad te vergemaklik tussen Suid Afrika en buitelandse state. Die ICCMA bestaan uit vyf hoofstukke maar die oorgrote meerderherd van regspraak afkomstig van Suid Afrikaanse howe her gehandel met die hoofstuk wat betrekking het op die verkryging en toelaatboorherd van getuienis. Dit is gevolglike teen hierdie agtergrond wat hierdie artikel focus op die aspekte rakende getuienis wat deur die Suid Afrikaanse howe behandel is. Die doel van hierdie artikel is gevolglik om aan te toon hoe Suid Afrikaanse howe die bepairngs van die Wet rakende getuienis, geinterpreteer het. 'n Aanbeveling word gevolglik voorsien ten aansien van hoe artikel gewysig kan word.

\section{Introduction}

South Africa has adopted different initiatives to cooperate with other countries in the fight against crime. These have included the signing of bilateral agreements on issues such as mutual legal assistance in criminal matters ${ }^{1}$ and extradition; ${ }^{2}$ the ratification of multilateral treaties on

* I am grateful to Professor Israel Leeman for his comments on the earlier draft of this article. The usual caveats apply. Email: djmujuzi@gmail.com

1 Countries with which South Africa has signed treaties on mutual legal assistance in criminal matters include Canada, USA, Lesotho, Egypt, Algeria, Nigeria, France, China, and India. See http://www.justice.gov.za/ilr/ mla.html (accessed 2014-01-13).

2 South Africa has extradition agreements with several countries including Botswana, Lesotho, Malawi, Swaziland, USA, Canada, Australia, Israel, Egypt, Algeria, Nigeria, China and India.

How to cite: Mujuzi 'The South African International Co-operation in Criminal Matters Act and the issue of 
issues such as corruption, ${ }^{3}$ organised crime ${ }^{4}$ and extradition; ${ }^{5}$ and the enactment of domestic pieces of legislation such as those dealing with the collection of evidence from other countries ${ }^{6}$ and those giving South African courts jurisdiction over offences committed outside South Africa. $^{7}$ In 1996 the South African legislature enacted the International Co-operation in Criminal Matters Act ('ICCMA'). ${ }^{8}$ In 1997 the Regulations under the ICCMA were promulgated to operationalise the Act. ${ }^{9}$ The purpose of the Act is to 'facilitate the provision of evidence and the execution of sentences in criminal cases and the confiscation and transfer of the proceeds of crime between the Republic [of South Africa] and foreign States; and to provide for matters connected therewith'. ${ }^{10}$ The South African Department of Justice and Constitutional Development has indicated that there is an increase in the number of requests for extradition and mutual legal assistance. ${ }^{11}$ It appears that most of these requests come from African countries. ${ }^{12}$ However, this information is

3 South Africa ratified the United Nations Convention against Corruption, United Nations Treaty Series vol. 2349 p 41; Doc. A/58/422 in November 2004.

4 South Africa ratified the United Nations Convention against Transnational Organised Crime in February 2004.

5 For example, South Africa acceded to the Council of Europe's Convention on Extradition in 2003 and ratified the SADC Protocol on Extradition in 2003.

6 See, for example, Documentary Evidence from Countries in Africa Act No 62 of 1993 and Foreign Courts Evidence Act No 80 of 1962.

7 See for example, the Prevention and Combating of Torture of Persons Act 13 of 2013 (which, inter alia, gives South African courts jurisdiction over the crime of torture committed outside South Africa) and the Protection of Constitutional Democracy Against Terrorists and Related Activities Act No 33 of 2004 (which gives South African courts jurisdiction over the offence of terrorism committed outside South Africa).

8 Act No 75 of 1996.

9 Regulations under the ICCMA GNR 1729 of 1997-12-19, GG No 18556

10 Long title of the ICCMA.

11 'The Department dealt with 133 requests for extradition and mutual legal assistance cases during the year under review, compared to the 99 handled during the 2011/12 financial year. This is a clear indication of the intentions of the country to deal decisively with transnational crime'. See Annual Report of the Department of Justice and Constitutional Development $2012 /$ 2013 (August 2013) 33. Available at http://www.justice.gov.za/reportfiles/ anr2012-13.pdf ; in its 2013/2014 annual report, the Department reported that "during the year under review, the Department received 154 requests for extradition and mutual legal assistance, 58 of those requests did not comply with the Act and had to be referred back to the requestors. A total of 77 of 94 valid requests were processed within the prescribed time frames, translating into 82\% achievement'. See Annual Report 2013/2014 at 70; available at www.gov.za/sites/www.gov.za/files/doj\% 20anr2013-14_a.pdf.

12 'During the year under review, the Directorate: International Legal Relations (Africa and South) received 131 requests for extradition and mutual legal assistance in criminal matters. Of these requests, 32 had to be returned to the respective states, as the requests did not comply with South Africa's domestic law. A total of 99 valid requests have been processed and channelled to the NPA and/or Interpol for execution'. See South African Yearbook 2012-2013 at 423; available at http://www.justice.gov.za/about/sayearbook/2012-13_chp15_sayearbook.pdf. 
silent on the number of requests made by and to South Africa on the basis of the ICCMA. The ICCMA has five chapters: Chapter one deals with definitions; chapter two with mutual provision of evidence; chapter three with mutual execution of sentences and compensatory orders; chapter four with confiscation and transfer of proceeds of crime; and chapter five with miscellaneous issues. It is beyond the scope of this article to deal with all five chapters. The purpose of this article is to show how South African courts have interpreted the provisions of the ICCMA relating to the issue of evidence.

\section{The Definition of 'Evidence'}

The ICCMA defines 'evidence' to include 'all books, documents and objects produced by a witness'. ${ }^{13}$ The ICCMA uses the word 'evidence' in some sections and 'information' in other sections and this has been the subject of debate before South African courts. In Beheersmaatschappij Helling I NV and Others $v$ Magistrate, Cape Town, and Others, the High Court held that evidence 'is widely defined in the Act'. ${ }^{14}$ Section $2(2)$ of the ICCMA empowers a judge, in chambers, or a magistrate to issue a letter requesting assistance from a foreign state for 'information' as stated in the letter of request for the purposes of an investigation relating to an alleged offence. As will be illustrated later, section 2(1) uses the word 'evidence' and not 'information'. Section 2(2) does not use the word 'evidence' but rather 'information'. However, section 5 of the ICCMA provides that 'evidence' obtained on the basis of a letter of request - whether issued on the basis of section 2(1) or 2(2) - is admissible. Therefore, when a letter of request is issued in terms of section 2(1), evidence is being sought but what is sought from a foreign state, on the basis of section 2(2), is not evidence, but information which is needed for the purpose of investigating whether or not the alleged offence was committed. Once that information confirms that the alleged offence was committed and it is adduced before a court for the purpose of prosecution, it becomes evidence. In other words, it mutates from information to evidence. In National Director of Public Prosecutions $v$ Jacob Gedleyihlekisa Zuma and Others ${ }^{15}$ one of the issues was the meaning of the word 'information' in section 2(2). The applicants argued that information obtained on the basis of section 2(2) should not be elevated to the level of evidence unless the person about whom that information was gathered had been given an opportunity to be heard in the process of collecting the information. The Court held that information 'does not simply mean knowledge gleaned or intelligence received' and that the legislature was aware of the differences between sections 5(5) and 2(1)

13 S 1

14 Beheersmaatschappij Helling I NV and Others $v$ Magistrate, Cape Town, and Others 2007 (1) SACR 99 (C) at 109. The reasoning in this case was endorsed in S v Miller and Others (SS13/2012) [2015] ZAWCHC 118 2015-92) par 54

15 The National Director of Public Prosecutions $v$ Jacob Gedleyihlekisa Zuma and Others (Case No 13569/2006) (2007-04-02). 
and, further, that it 'did indeed envisage a situation that in the [later] phase evidence could be obtained'. The Court added that the definition of 'evidence' in the ICCMA was broad enough to encompass 'documents'. ${ }^{16}$ The case went on appeal and the Supreme Court of Appeal held that: ${ }^{17}$

The construction that the appellants place on s 2(2) would mean that once a criminal investigation has established that an offence has been committed, evidence in a foreign state to prove the commission of the offence may only be secured by the prosecution after a trial has commenced. In my view that would be an absurd result that could not have been intended by the legislature.

A criminal investigation, in ordinary language, is conducted not only to inform the investigator whether an offence was committed, but also to gather evidence that will prove its commission in due course. I see no reason to give the word the restricted meaning that is contended for by the appellants. I think it follows that the word 'information' is similarly not confined to knowledge of whether an offence was committed, and least of all to knowledge that is as yet unknown, but extends to known facts recorded in documentary form that might provide evidence of the commission of the offence. That construction is supported by the provisions of $s 5(2)$, which contemplates a request for assistance yielding evidence that might be admissible in subsequent criminal proceedings. In my view what is required to be shown under s 2(2) is only that a criminal investigation (which includes the gathering of evidence for a prosecution) is underway and that it is necessary to elicit the assistance of a foreign state to obtain information (which includes known facts in documentary form) for purposes of that criminal investigation. In my view the section plainly permitted assistance to be sought to obtain possession of the documents and authenticating statements that are now in issue.

The applicants appealed to the Constitutional Court. However, the Constitutional Court dismissed the appeal by holding, inter alia, that 'information is not restricted to new and/or unknown knowledge. It extends to any knowledge, known or unknown'. ${ }^{18}$ The Constitutional Court added that ' $[\mathrm{t}$ ] o distinguish between information and evidence as the applicants did is therefore to draw a false distinction'. ${ }^{19}$ Furthermore, the National Director of Public Prosecutions requested the Court to issue a letter of request so that fourteen original documents could be obtained from Mauritius for the purpose of prosecuting the applicants for corruption. However, one wonders if the court's approach would have been the same if the information in question could not easily be classified as a book, a document or an object.

16 Idem at 13

17 Thint (Pty) Ltd $v$ National Director of Public Prosecutions and Others [2007] SCA 138 (RSA); [2008] 1 All SA 229 (SCA) parr 13-14.

18 Thint Holdings (Southern Africa) (Pty) Ltd and Another $v$ National Director of Public Prosecutions, Zuma v National Director of Public Prosecutions 2008 (2) SACR 557 (CC); 2009 (1) SA 141 (CC); 2009 (3) BCLR 309 (CC) par 38.

19 Idem par 39. 
It would appear that if, in a letter of request, the South African authorities request a foreign state for assistance in searching for and seizing 'documentation' and anything that does not fall squarely within the definition of 'documentation' is obtained and adduced in evidence, its admissibility could be challenged successfully in a South African court. In Beheersmaatschappij Helling I NV and Others $v$ Magistrate, Cape Town, and Others the letter of request from the Dutch authorities requested the South African authorities to assist in gathering information that was needed in the investigation of an alleged crime. A search warrant issued by a South African magistrate authorised the police to search for and seize the relevant documentation. In executing the warrant, the police seized computer hardware, software and peripherals. In holding that the search and seizure were invalid, the High Court held that ' $[\mathrm{b}] \mathrm{y}$ no stretch of the imagination could all the computer hardware, software and "peripherals" mentioned in Annexure A to the ... search warrants be classified as "documentation". The warrants merely authorise the police 'to search' certain persons and premises and 'to seize the said documentation as per Annexure A if found'. ${ }^{20}$

\section{South African Court Issuing a Letter of Request: Section 2 of the ICCMA}

Section 2 of the Act provides that:

(1) If it appears to a court or to the officer presiding at proceedings that the examination at such proceedings of a person who is in a foreign State, is necessary in the interests of justice and that the attendance of such person cannot be obtained without undue delay, expense or inconvenience, the court or such presiding officer may issue a letter of request in which assistance from that foreign State is sought to obtain such evidence as is stated in the letter of request for use at such proceedings.

(2) A judge in chambers or a magistrate may on application made to him or her issue a letter of request in which assistance from a foreign State is sought to obtain such information as is stated in the letter of request for use in an investigation related to an alleged offence if he or she is satisfied - (a) that there are reasonable grounds for believing that an offence has been committed in the Republic or that it is necessary to determine whether an offence has been committed; (b) that an investigation in respect thereof is being conducted; and (c) that for purposes of the investigation it is necessary in the interests of justice that information be obtained from a person or authority in a foreign State.

(3) Subject to subsection (4), a letter of request shall be sent to the DirectorGeneral for transmission - (a) to the court or tribunal specified in the letter of request; or (b) to the appropriate government body in the requested State.

(4)(a) In a case of urgency a letter of request may be sent directly to the court or tribunal referred to in subsection (3)(a), exercising jurisdiction in the

20 Beheersmaatschappij Helling I NV and Others $v$ Magistrate, Cape Town, and Others supra n 14 at 115. 
place where the evidence is to be obtained, or to the appropriate government body referred to in subsection (3)(b).

(b) The Director-General shall as soon as practicable be notified that a letter of request was sent in the manner referred to in paragraph (a) and he or she shall be furnished with a copy of such a letter of request.

Most of the jurisprudence that has emerged from South African courts has dealt with section 2 of the ICCMA. There is a distinction between the procedure in section 2(1) and that in section 2(2). This distinction has been emphasised in different court cases. In Thint Holdings (Southern Africa) (Pty) Ltd and Another $v$ National Director of Public Prosecutions, Zuma $v$ National Director of Public Prosecutions the Constitutional Court held that ' $[\mathrm{t}]$ he meaning of the section [2(1)] is clear: the letter of request is issued in court and not by a judge in chambers or a magistrate. The application is therefore made to the court by the investigator during, and not outside of, the criminal proceedings'. ${ }^{21}$ The Court added that under section 2(2), an application is made outside court proceedings 'before a judge in chambers or a magistrate, thereby permitting a request to be made even before commencement of criminal proceedings and during investigations'. ${ }^{22}$ The Court added that: ${ }^{23}$

For a letter of request to be granted, it is required that the judge or magistrate be satisfied that each of the jurisdictional requirements under section 2(2) has been met. Save for the question as to whether or not the information sought is necessary in the interests of justice, which under subsection 2(2)(c) is determined in the discretion of the judicial officer of the court, all the jurisdictional requirements are facts which must be proved.

In National Director of Public Prosecutions v In Re: An Application for the Issuing of a Letter of Request in terms of Section 2(2) of the International Cooperation in Criminal Matters Act No 75 of 1996, Ex Parte ${ }^{24}$ the High Court held that there is "a clear distinction between section 2(1) and section $2(2)$ of the Act ... "very different requirements, very different processes and different consequences attach to the two processes", 25 The Court added that: ${ }^{26}$

21 Idem par 26

22 Idem par 27

23 Idem par 29. During the debates in Parliament on the ICCM Bill, one Member of Parliament submitted that 'the Bill ... deals with improving cooperation between South Africa and other countries in obtaining evidence on criminal offences. The most important innovation in this law is to try get around the rather cumbersome process of taking evidence on commission. The law now provides for judicial officers to issue a letter of request for evidence and for a speedy procedure to obtain that evidence from overseas'; submission by Mr WA Hofmeyr Debates of the National Assembly (Hansard) Third Session First Parliament, 15 January to 7 November (1996) at 4997-4998.

24 National Director of Public Prosecutions $v$ In Re: An Application for the Issuing of a Letter of Request in terms of Section 2(2) of the International Co-operation in Criminal Matters Act No 75 of 1996, Ex Parte (71/07/01) [2007] ZAGPHC 197 (2007-09-14)

25 Idem 8.

26 Ibid. 
Section 2(1) must be followed when proceedings are before a court. The state can make use of the provisions of section 2(2) of the act when there are no proceedings before a court and when the state wants to gather information in order to decide whether to bring such proceedings before a court. In the section 2(1) proceedings the person involved in the proceedings before the court has an interest in the application. In the section 2(2) application the person whose affairs are being investigated has no interest in the investigation because the investigation as such may not lead to proceedings before a court. Once the investigation does lead to proceedings before a court the provisions of section 5 of the act apply.

The distinction between section 2(1) and section 2(2) means that it is crucial that the legal status of the individual in question is clearly understood. If the individual in question is an accused, then section 2(1) is applicable. In South African law, an accused has a right to a fair trial which is guaranteed under section 35(3) of the Constitution. It is against that background that an accused has an interest in whether or not a letter of request should be granted in terms of section 2(1). If the individual is a suspect, section 2(2) of the ICCMA is applicable. If a matter is struck from the court's roll before the individual pleads to the charge or charges, a letter of request has to be issued on the basis of section 2(2) and not section 2(1). ${ }^{27}$ The Constitutional Court held that '[o]nce a case is struck from the roll, the case terminates and is no longer pending. There is no guarantee that the criminal proceedings will be reinstated. Removal of a matter from the roll is therefore abortive of the currency of the trial proceedings'. 28

The Court added that whether or not criminal proceedings are pending against the individual is an objective fact and that '[i]t cannot be said therefore that once the matter had been struck from the roll, the proceedings were still pending'. ${ }^{29}$ It does not matter whether or not the matter was struck from the roll due to the prosecutor's inability to proceed with the prosecution. What matters is that there are no criminal proceedings pending against the person. It is submitted that if the charges are withdrawn on the basis of section 6(a) of the Criminal Procedure Act ('the CPA'), ${ }^{30}$ the individual, as is the case where the case is struck from the roll by the court, ceases to be an accused and a letter of request has to be issued on the basis of section 2(2). The Supreme Court of Appeal held that the word 'proceedings', as used in section 2(1) of the ICCMA, means 'the trial of a person on a criminal charge, which commences when the person who stands accused is called upon to plead

27 Ibid.

28 Thint Holdings (Southern Africa) (Pty) Ltd and Another $v$ National Director of Public Prosecutions, Zuma $v$ National Director of Public Prosecutions supra $n$ 18 at par 41 .

29 Idem par 43.

30 Act 51 of 1977 ; s 6(a) provides that the Director of Public Prosecutions or any prosecutor, whether public or private, may 'before an accused pleads to a charge, withdraw that charge, in which event the accused shall not be entitled to a verdict of acquittal in respect of that charge'. 
to the charge'. ${ }^{31}$ Therefore, even if a person has been indicted but the trial has not yet commenced - that is, he has not pleaded to the charges against him - that person is not an accused and there are no proceedings. $^{32}$ Section $2(1)$ does not oblige a court, before which the proceedings are pending, to issue a letter of request. In $S v O k a h^{33}$ the Court emphasised the fact that it had the discretion to issue a letter of request to obtain evidence from abroad. ${ }^{34}$ If the accused refuses to call witnesses or evidence from abroad, a court cannot 'disregard the accused's election and superimpose upon the accused its own election by issuing a letter of request mero motu calling for the evidence of such witnesses' ${ }^{35}$ This means that unlike cases where the witnesses are based in South Africa and the court can invoke its power to subpoena witnesses on the basis of section 186 of the CPA, ${ }^{36}$ in cases where the defence witnesses are based abroad and the accused objects to the introduction of evidence in court, a court cannot call for that evidence.

31 Thint (Pty) Ltd $v$ National Director of Public prosecutions and Others supra $n$ 17 at par 10 .

32 Ibid.

33 S v Okah (Case No: SS94/11) (2013-03-20).

34 Idem par 32; see also S v Basson 2007 (1) SACR 566 (CC) parr 85-86, where the Constitutional Court held '[t]he State applied for the Court to allow it to call $\mathrm{Mr}$ Buffham as a witness as, allegedly, his evidence would have seriously contradicted that of the respondent who had testified that $\mathrm{Mr}$ Buffham was an employee of the financial principals who had channelled funds to the respondent. The Court would have been entitled to call $\mathrm{Mr}$ Buffham in terms of the [ICCMA]if it considered that his evidence was "necessary in the interests of justice". However, the Court refused to call $\mathrm{Mr}$ Buffham, but drew conclusions regarding his credibility without having heard him. To quote the learned Judge: "Yes, Buffham was a wheeler and dealer if you ever saw one". The State argued that this comment and the failure to call $\mathrm{Mr}$ Buffham gave rise to a reasonable apprehension of bias. We cannot agree. The Judge had a discretion as to whether to take steps to call Mr Buffham. In the exercise of that discretion, he had to consider whether Mr Buffham's evidence was 'necessary in the interests of justice'. It is clear that from other evidence the Judge had heard concerning $\mathrm{Mr}$ Buffham, he doubted his credibility which informed his decision that $\mathrm{Mr}$ Buffham's evidence was not necessary in the interests of justice'.

35 Sv Okah supra n 33 at par 37.

36 S 186 of the CPA provides " $t$ t]he court may at any stage of criminal proceedings subpoena or cause to be subpoenaed any person as a witness at such proceedings, and the court shall so subpoena a witness or so cause a witness to be subpoenaed if the evidence of such witness appears to the court essential to the just decision of the case'. In $S v$ Basson (supra $n 34$ at par 75), the state argued, inter alia, that the presiding judge has been biased against it as he had failed to invoke section 186 to call three witnesses. The Constitutional Court referred to section 186 of the CPA and held that "it is for the Court to determine whether the evidence of the witnesses is "essential to the just decision" of the case. In considering this, the Court was entitled to consider the right of the accused that the trial be concluded within a reasonable time. It was further relevant that the State sought that the evidence from these witnesses be received on commission which might have precluded Dr Basson from being present during their testimony and would have been very costly'. 
This raises the issue of whether there are any circumstances in which a court may be obliged, in the interest of justice, to call for such evidence. For example, if the accused is unrepresented and does not appreciate the likely grave consequences of not calling such an important witness. It is argued that section 2(1) of the ICCMA does not bar a court from issuing a letter of request mero muto for the witness who is based abroad to give evidence on the basis of that letter. This is so because unlike section 2(2), where a court can only issue a letter of request on the basis of an application made to it, a court can exercise its discretion, without such application, to issue such a letter. ${ }^{37}$ Section 2(1) of the ICCMA allows a court to issue a letter of request 'if it appears' to that court that the examination of a witness in a foreign country 'is necessary in the interest of justice'. In $S v$ Basson, the High Court held that section 2(1) 'deals with witnesses in foreign countries. It cannot be construed ... as only dealing with cases where the witness is temporarily unavailable through illness or some other mishap,. ${ }^{38}$ Although in all cases that have been decided by South African courts the witnesses were permanently resident abroad, section 2(1) applies whether the witness is temporary or permanently in a foreign country and if his attendance cannot be obtained without undue delay, expense or inconvenience. The witness in question could be a South African resident or citizen or a foreign citizen.

As regards the issue of whether there are circumstances in which a court can exercise its discretion to call a witness even if the accused has not applied for that witness to be called or is opposed to the calling of such witness, although according to South African law a judge is generally not supposed to 'descend into the arena', in other words, should base his decision on the evidence led by the parties to the proceedings, it is argued that there could be circumstances where a judge may be justified in issuing a letter of request for evidence that could exonerate the accused to be brought from abroad if he thinks it is necessary in the interest of justice for such evidence to be before the court. The judge might come to know of the existence of such evidence through the evidence led by the prosecution. The High Court has held that " $[\mathrm{t}] \mathrm{he}$ prosecutor is under the legal duty to present all relevant evidence to the court, even if it damages the State's case'. 39 If the accused is represented, and the prosecutor knows of evidence or a witness that might weaken the state's case and strengthen that of the accused, he has a duty to disclose such information to the accused's lawyer. The Supreme Court of Appeal in $S \mathcal{v}$ Van der Westhuizen held, inter alia, that: ${ }^{40}$

[I]f there is evidence which the prosecutor knows or ought reasonably to suspect is or may be destructive of the State case, or which tends or might tend to support the defence case, and which the prosecutor knows or ought

37 In $S v$ Basson 2000 (2) SACR 188 (T) at 193, the Court observed that " $\mathrm{t}$ ] he court has a discretion to issue a letter of request when it "appears ... that the examination ... of a person ... is necessary in the interest of justice".'

38 Idem at 193.

39 Sv Mofokeng 2004 (1) SACR 349 (W) par 22.

40 S v Van der Westhuizen 2011 (2) SACR 26 (SCA) par 13. 
reasonably to suspect is not known to the defence, it is the prosecutor's duty to bring this evidence specifically to the attention of the accused's legal representatives.

It is submitted that even if such witness is based outside the country, the prosecutor has a duty to disclose his presence to the accused's lawyer. However, if the accused insists that the witness in question should not be called to give evidence, his lawyer should not call such witness. The defence lawyer has to act in accordance with his client's instructions. ${ }^{41}$

\section{Interests of Justice}

Section 2(1) of the ICCMA provides that a court may issue a letter of request if it 'is necessary in the interests of justice'. However, the ICCMA does not stipulate the factors that a court has to consider in determining whether the information sought is necessary in the interests of justice. The Constitutional Court held that: ${ }^{42}$

Whether the information sought is necessary in the interests of justice will derive from the circumstances of each case. A determination of the interests of justice must take into account and balance the relevant rights, duties and interests involved ... [I]ndividuals who may be affected by the issue of letters of request possess constitutional rights which must be respected. On the other hand, the public has an interest in the effective prosecution of crime and the state thus bears a duty to take all reasonable and lawful steps to obtain information necessary for the effective prosecution of crime. What is necessary in the interests of justice must be determined in the exercise of the court's discretion taking into account the surrounding facts and circumstances of the case.

In $S v$ Basson, ${ }^{43}$ the Court dismissed an application for a letter of request for evidence to be obtained from the United Kingdom because the evidence in question was 'not necessary. It can only be said to have the potential of being useful'. ${ }^{44}$ The Court outlined some of the factors that could be considered in determining whether or not it was necessary in the interest of justice to issue a letter of request: ${ }^{45}$

(1) Although the State normally has an unfettered discretion as to who is to be called as a witness, in matters of this kind the court has limited powers to prescribe to the State, or to whoever brings such an application, that it may not avail itself of the evidence of a particular witness.

(2) The evidence which the witness in question can give must be: (1) necessary, (2) relevant, and (3) admissible.

41 For the role of the defence lawyer towards his client, see $S v$ Mofokeng supra n 39.

42 Thint Holdings (Southern Africa) (Pty) Ltd and Another $v$ National Director of Public Prosecutions, Zuma v National Director of Public Prosecutions supra $\mathrm{n}$ 18 at par 30

43 S v Basson 2001 (1) SACR 235 (T)

44 Idem at 240.

45 Idem at 236. 
(3) The court may look at the reasons for the witness' inability or refusal to testify at the trial and may draw inferences therefrom.

(4) Where the State is the applicant, the court is entitled to look at the probable expenses which the State, and therefore the taxpayer, will have to incur. If it will be substantial, it will not be wrong to compare the probable weight of such evidence to the prospective expenses. Unless the expenses are clearly justified, the court can regard the expenses as a factor negative to the applicant.

(5) The court must weigh up the prejudice which the applicant will suffer, if the request is not granted, against the prejudice which the respondent will suffer if the request is granted.

The Court concluded that it would not be in the interests of justice to issue a letter of request because of, inter alia, the little value that the evidence in question would add to the trial, the heavy cost involved in acquiring such evidence, and the fact that the accused's trial would be delayed. In $S v$ Basson $^{46}$ the prosecution applied for a letter of request to be issued to the United States of America ('USA') authorities to have some state witnesses who were living in the USA and unwilling to come to South Africa, examined. The Court, in issuing that letter of request, held that: 47

The main consideration is the interests of justice. The qualification that it cannot be obtained without undue delay, expense or inconvenience, merely gives an indication under what circumstances a court will exercise the discretion. The fact that the witness refuses to come to this country will definitely cause an undue delay in terms of the section.

In $S v$ Basson $^{48}$ the Court seems to suggest that one of the ways in which the cost involved in obtaining evidence from abroad, when the witness refuses to come to South Africa and testify, is for the presiding judge to be appointed as one of the commissioners. Hartzenberg J, in recommending that he should be appointed as commissioner, reasoned that '[i]f I am appointed as commissioner, the extra expenses relating to the making of a video recording can be avoided and, more importantly, the tedious process of informing the court what happened at the interrogation, together with extra costs caused by the days spent thereon, can also be avoided'. ${ }^{49}$ However, the Court was aware of some of the challenges that are associated with the presiding judge being appointed as a commissioner.

The relationship between section 2 of the ICCMA and other pieces of legislation is worth mentioning. The case of Lawrence Goldberg and Another $v$ Magistrate $R$ Boshoff $N O$ and Another ${ }^{50}$ dealt with the

$46 \quad S v$ Basson supra $n 37$.

47 Idem at 193.

48 Ibid.

49 Idem at 198.

50 Lawrence Goldberg and Another $v$ Magistrate R Boshoff NO and Another (Case No. 09/53076) [2010] ZAGPJHC 164 (2010-7-30). 
relationship between sections $2(1)$ and $31^{51}$ of the ICCMA and section 158 of the CPA. Section 158 of the CPA provides that:

(1) Except as otherwise expressly provided by this Act or any other law, all criminal proceedings in any court shall take place in the presence of the accused.

(2)(a) A court may, subject to section 153, on its own initiative or on application by the public prosecutor, order that a witness or an accused, if the witness or accused consents thereto, may give evidence by means of closed circuit television or similar electronic media.

A court may make a similar order on the application of an accused or a witness.

(3) A court may make an order contemplated in subsection (2) only if facilities therefor are readily available or obtainable and if it appears to the court that to do so would - (a) prevent unreasonable delay; (b) save costs; (c) be convenient; (d) be in the interest of the security of the State or of public safety or in the interests of justice or the public; (e) prevent the likelihood that prejudice or harm might result to any person if he or she testifies or is ...

(4) The court may, in order to ensure a fair and just trial, make the giving of evidence in terms of subsection (2) subject to such conditions as it may deem necessary: Provided that the prosecutor and the accused have the right, by means of that procedure, to question a witness and to observe the reaction of that witness.

Relying on sections 2(1) and 31 of the ICCMA, and section 158 of the CPA, the magistrate granted the state's application that the authorities in the United Kingdom should be requested to secure: ${ }^{52}$

$[T]$ he attendance of the ... witnesses at a venue in the United Kingdom from where the court ... sitting in [South Africa], would receive their evidence by means of electronic media equipment. The witnesses [were] to be examined, cross-examined, and re-examined by electronic means from the courtroom in [South Africa].

The issue before the High Court was whether the magistrate could legally issue a letter of request in terms of which witnesses in a foreign state would be examined, cross-examined and re-examined by electronic means from a courtroom in South Africa. ${ }^{53}$ The High Court held that: ${ }^{54}$

The learned regional magistrate has no authority, either in terms of the provisions of s[ection] 2(1) of the ICCMA or in terms of the provisions of s[ection] 158 of the CPA, to issue a letter of request in which the relevant authorities in the United Kingdom are requested to arrange and facilitate the attendance of witnesses at a venue in the United Kingdom from where they,

51 S 31 states: 'Nothing in this Act contained shall be construed so as to prevent or abrogate or derogate from any arrangement or practice for the provision or obtaining of international co-operation in criminal matters otherwise than in the manner provided for by this Act'.

52 Lawrence Goldberg and Another $v$ Magistrate R Boshoff NO and Another supra n 50 at par 2.

53 Idem par 4.

54 Idem par 13. 
by electronic means, would give their evidence at the proceedings in the court a quo. Such power and procedure cannot be read into the clear wording of these statutory provisions.

The Court added that: ${ }^{55}$

The relevant provisions of the ICCMA permit the examination at proceedings in the foreign state of a person who is in the foreign state, if the evidence of such person is 'necessary in the interests of justice' in the proceedings before a court of this country and 'the attendance of such person cannot be obtained without undue delay, expense, or inconvenience'. Judicial authorisation to request this form of assistance from a foreign state is required and is given when a court issues a letter of request ...

The provisions of s[ections] 158(2) - (5) of the CPA concern the giving of evidence by an accused or by a witness through closed circuit television or similar electronic media at local proceedings in a criminal court and the circumstances under which the court may order that the evidence be given through such media. These provisions do not permit a procedure for the taking of evidence across borders by electronic means at a local criminal trial. Nothing in these subsections suggest an '... arrangement or practice for the provision or obtaining of international co-operation in criminal matters' as was submitted to us by the second respondent's counsel.

It is clear that although there could be circumstances in which courts may rely on the provisions of other pieces of legislation to implement a relevant section of the ICCMA, care should be taken to ensure that they do not invoke provisions that were designed exclusively for local application. In $S v$ Basson, the Court held that South African courts can request that the questioning of a witness in terms of section 2(1) in a foreign country be conducted in accordance with South African procedure. ${ }^{56}$ However, in Lawrence Goldberg and Another $v$ Magistrate $R$ Boshoff NO and Another, the Court held that: 57

The law and procedure of the foreign state apply to the proceedings at the examination of the witness abroad. Such proceedings at which the witness is examined are not proceedings of the court which issued the letter of request. The evidence obtained at such proceedings is admitted as evidence by the court which issued the letter of request '... in so far as it is not inadmissible at such proceedings.

The Court in $S v$ Basson based its above conclusion on information supplied to it by a witness from the USA who stated 'that this Court can request the district court to order that the South African procedure is to be followed, ${ }^{58}$ It is against that background that the Court held that: ${ }^{59}$

55 Idem parr 15-16

56 S v Basson supra $\mathrm{n} 37$ at 196.

57 Lawrence Goldberg and Another $v$ Magistrate R Boshoff NO and Another supra n 50 at par 15 .

$58 \quad$ S v Basson supra $\mathrm{n} 37$ at 196.

59 Ibid. 
It seems obvious to me that the witnesses of necessity will be entitled to all protection according to the United States law. On the other hand the questioning of the witnesses will have to accord with the South African procedure and law of evidence to be admissible at the hearing.

In my opinion, the judgement in Lawrence Goldberg and Another $v$ Magistrate R Boshoff NO and Another reflects the correct legal position. If the procedure in the foreign country does not meet international minimum standards relating to the examination of witnesses for the purpose of a prosecution, the admissibility of such evidence could successfully be challenged in a South African court. As mentioned earlier, section 2(2)(b) of the ICCMA provides that a judge in chambers or a magistrate may issue a letter of request if he or she is satisfied 'that an investigation in respect thereof is being conducted'. It would appear that this provision is broad enough to empower a judge or magistrate to issue a letter of request even if the investigation is being conducted outside South Africa.

\section{Letters of Request from Foreign Countries to South Africa}

Section 7 of the ICCMA provides that:

(1) A request by a court or tribunal exercising jurisdiction in a foreign State or by an appropriate government body in a foreign State, for assistance in obtaining evidence in the Republic for use in such foreign State shall be submitted to the Director-General.

(2) Upon receipt of such request the Director-General shall satisfy himself or herself - (a) that proceedings have been instituted in a court or tribunal exercising jurisdiction in the requesting State; or (b) that there are reasonable grounds for believing that an offence has been committed in the requesting State or that it is necessary to determine whether an offence has been so committed and that an investigation in respect thereof is being conducted in the requesting State.

(3) For purposes of subsection (2), the Director-General may rely on a certificate purported to be issued by a competent authority in the State concerned, stating the facts contemplated in paragraph (a) or (b) of the said subsection.

(4) The Director-General shall, if satisfied as contemplated in subsection (2), submit the request for assistance in obtaining evidence to the Minister for his or her approval.

(5) Upon being notified of the Minister's approval the Director-General shall forward the request contemplated in subsection (1) to the magistrate within whose area of jurisdiction the witness resides.

In Thatcher $v$ Minister of Justice and Constitutional Development and Others $^{60}$ the Court held that the Minister's decision in terms of section 7 'is not a purely legal exercise'. It involves the application of the laws of

60 Thatcher $v$ Minister of Justice and Constitutional Development and Others 2005 (1) SACR 238 (C) 
both the requesting state and South African. ${ }^{61}$ The Court added that section 7 'does not require the requesting state to motivate or substantiate its request. Provided it is a genuine request made in good faith it should, and would in all probability, be accepted as such'. ${ }^{62}$ If the Director-General is satisfied that proceedings have been instituted in a court or tribunal in the requesting state, he does not have to consider the second ground in section $7(2){ }^{63}$ The Director-General's function, in terms of section $7(2)$, is 'purely administrative'. ${ }^{64}$ All the DirectorGeneral is required to do is to arrange for the request and supporting documentation to be sent to the Minister. He is 'not required to consult with or advise [the Minister], but merely to await [the Minister's] decision for the purpose of conveying it ... to the magistrate. ${ }^{65}$ In deciding whether or not to approve the request from a foreign country, the Minister may have 'regard to political and foreign policy considerations, ${ }^{66}$

Sections 28 and 29 of the ICCMA empower the Minister and the Director-General, respectively, to delegate any function conferred upon them to an official of the Department of Justice. In Tulip Diamonds FZE $v$ Minister of Justice and Constitutional Development and Others ${ }^{67}$ one of the issues before the Constitutional Court was whether the Director-General's delegation of his authority, in terms of section 7(5), of the ICCMA to a Deputy Chief State Law Adviser was valid. The Court held that the delegation in question was lawful because it met the requirements of section 29 of the ICCMA and that the applicant who challenged the delegation had failed to prove that the Director-General did not 'have the proper substantive delegating authority'. ${ }^{68}$ As will be shown shortly, case law indicates that South Africa has received letters of request on the basis of section 7 from countries, such as Equatorial Guinea, The Netherlands and Germany.

For a letter of request to be issued, section 7(5) requires that the request be approved by the Minister of Justice unless the Minister delegates that responsibility to an official in the Department of Justice in accordance with section 28 of the ICCMA. Section 28 empowers the Minister to delegate to an official of the Department of Justice any function conferred upon him or her by the ICCMA, except the function of making regulations in terms of the Act. In Beheersmaatschappij Helling I $N V$ and Others $v$ Magistrate, Cape Town, and Others the High Court

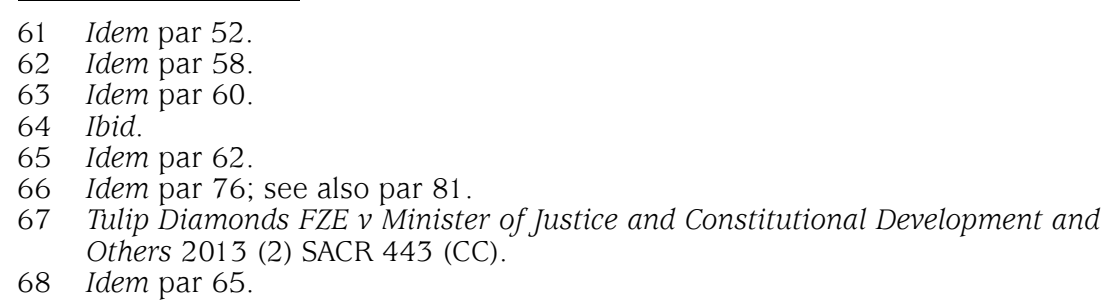


explained why the legislature entrusted that responsibility to the Minister. The Court held that: 69

Moreover, there is, it seems to me, a need for such requests, before being blindly complied with by the police or the prosecuting authorities, first to be considered and approved at a higher level. There may well be, and probably are, countries ... with which co-operation in these matters may be considered (at ministerial level) to be unwarranted or undesirable for a variety of reasons, for example, because the system of criminal justice in those countries is disturbingly inadequate, or because of their refusal or failure to reciprocate in the past with assistance to South Africa. In such cases, reluctance on the part of our authorities to devote precious resources to assisting foreign States would be understandable and justifiable (in the present case, according to lists of names attached to the search warrants, it was envisaged that no less than 39 members of the South African Police Service, including ten commissioned officers, would take part in the searches: whether as many as that actually did so, does not appear). Moreover, the offences being investigated by the Dutch authorities appear to be of a predominantly fiscal nature. Historically, one State has, generally speaking, been loath to assist another to recover taxes allegedly due to the latter by, eg extradition. All of these are considerations which, no doubt, weighed with the Legislature when it passed s 7 of the Cooperation Act.

The above raises at least one critical issue - the role of the court in giving effect to the Minister's approval of a request for evidence to be obtained and transferred to a foreign country on the basis of section 7 . The Court held that the Minister may refuse to approve such request if he believes that the criminal justice system in the requesting state is disturbingly inadequate. It is not enough that the criminal justice system in the requesting state is inadequate; it has to be shown that the criminal justice system in a given country is disturbingly inadequate. One of the factors that the Minister may consider in such a case is whether there are reports from credible sources, such as international human rights bodies, that the criminal justice system in the requesting country is of such a nature that basic international fair trial norms are not complied with. However, the Minister's decision is a policy and political one and he may not concern himself with the adequacy or otherwise of the criminal justice system in the requesting state. This brings me to the question of the role of the courts in reviewing the Minister's approval.

In Thatcher $v$ Minister of Justice and Constitutional Development and Others, the Minister's approval for a letter of request from Equatorial Guinea was challenged. After the Minister had approved the letter of request, the applicant was subpoenaed by a magistrate to answer some questions which were attached to the letter of request (interrogatories). The answers to the questions were needed as evidence for the prosecution of foreign nationals - including eight South Africans who were on trial in Equatorial Guinea for allegedly trying to overthrow the government. The applicant argued, inter alia, that 'no assistance should

69 Beheersmaatschappij Helling I NV and Others v Magistrate, Cape Town, and Others supra n 14 at 110. 
have been afforded Equatorial Guinea in the conduct of its case against the eight South Africans ... in that they could not be expected to obtain a fair trial there'. ${ }^{70}$ He added that the answers to the questions could also be used to motivate for his extradition to stand trial in Equatorial Guinea for allegedly financing the alleged attempted coup and that if extradited, 'his trial ... would not be in accordance with the requirements of customary international law'. ${ }^{71}$ The respondents argued that: ${ }^{.2}$

[D]iplomatic protection had been furnished to the South African accused. During 'sensitive and diplomatic negotiations' the delegates from South Africa had received assurances from Equatorial Guinean authorities that South African nationals would, in accordance with 'the international standard of justice', have a fair trial and would not be subjected to torture. A South African delegation had in fact monitored the trial and was satisfied that it was fair.

In any event $\ldots$ the existence of negative reports on the human rights situation in Equatorial Guinea did not entitle the South African government to scrutinise the human rights record and criminal justice system of every country requesting it for information in a criminal trial or investigation. This would be contrary to the spirit of international co-operation prevailing between South Africa and such country.

The Court held that the Director-General: ${ }^{73}$

[W]as not required to take cognisance of the merits or demerits of the trial procedures in Equatorial Guinea or of the penal provisions (including the death penalty) which might be applicable in the event of a conviction. Nor was it necessary for him to give consideration to the alleged link between the applicant and the attempted coup, or to whether it might be in the interests of justice, or of the accused, to grant assistance.

The Court added that as is the case with the Director-General: ${ }^{74}$

It was ... not necessary for the [Minister] ... to satisfy herself that it would be 'in the interests of justice and in order to permit the accused to benefit from a fair trial' ... to approve the request. If, of course, she had suspected that the trial in Equatorial Guinea was unfair and would in all probability result in grave injustice for the accused, she would have been required to take account of this in making her decision.

As regards the likelihood that the evidence obtained from the applicant would be used at a trial at which the accused could be sentenced to death - in the light of the fact that South Africa had not sought the necessary assurance from Equatorial Guinea that the death penalty will not be imposed - the Court held that: ${ }^{75}$

70 Thatcher $v$ Minister of Justice and Constitutional Development and Others supra $\mathrm{n} 60$ at par 9.

71 Idem par 10.

72 Idem parr 30-31

73 Idem par 60

74 Idem par 75

75 Idem par 96 
Although Equatorial Guinea had given no undertaking that the death penalty would not be imposed if there should be a conviction, 'political assurances' had been given that the authorities would, in the event the death penalty was imposed, look favourably on a request to commute such penalty. In view of the rapidly improving co-operation between the two countries a positive outcome could be expected.

At least two concerns emerge from the above holding of the court. First, the fact that the Director-General and the Minister of Justice are not required to investigate whether or not the evidence being sought could be used at an unfair trial means that there is a risk that South Africa could consciously or unconsciously send evidence to a foreign state which could be used to dignify a trial that falls below internationally acceptable standards. Secondly, there is a danger that such evidence could be used at a trial at which the offenders faced a real risk of being sentenced to death, yet South Africa had abolished the death penalty. The judgement leaves open the possibility of challenging both the Director-General and the Minister's decisions if there is evidence that the handing over of evidence, to another country, would contribute towards a 'grave injustice' against the accused. The Minister's approval of the request could be challenged on the ground that it was irrational and unreasonable. ${ }^{76}$

In order to challenge the Minister's approval in terms of section 7 , a person, whether natural or juristic, does not have to be based in South Africa or be a South African citizen or resident. In Tulip Diamonds FZE $v$ Minister of Justice and Constitutional Development and Others, ${ }^{77}$ the applicant, a company registered in the United Arab Emirates, challenged the Minister's decision to approve a letter of request from the Belgian authorities requiring the applicant's courier to produce some documents needed to investigate a Belgian company and citizen for tax fraud. The documents were to be seized and copies thereof sent to Belgium. The applicant argued that the seizure of the documents would violate his confidentiality and right to privacy. One of the arguments against the application was that the applicant was not registered in South Africa and, therefore, did not have locus standi before a South African court to challenge the validity of the Minister's approval. The Supreme Court of Appeal held that for a person to institute legal proceedings in a South African court, that person 'must have a direct and substantial interest in the right which is the subject-matter of the litigation' ${ }^{78}$ The Court held that the applicant had locus standi because it had 'a protectable interest in this country, [and was] seeking to protect that interest before a South

76 Freedom Under Law $v$ National Director of Public Prosecutions and Others [2013] 4 All SA 657 (GNP) parr 127-129, where the High Court dealt with the circumstances in which a decision could be challenged for being illegal, irrational or unreasonable. See also National Director of Public Prosecutions and Others $v$ Freedom Under Law 2014 (4) SA 298 (SCA); 2014 (2) SACR 107 (SCA); [2014] 4 All SA 147 (SCA).

77 Tulip Diamonds FZE $v$ Minister of Justice and Constitutional Development and Others 2013 (1) SACR 323 (SCA).

78 Idem par 13 
African court'. ${ }^{79}$ However, the Supreme Court of Appeal's holding on the issue of standing was reversed by the majority in the Constitutional Court who held that the applicant lacked standing under both section 38 of the Constitution $^{80}$ and common law, as it failed to demonstrate that the disclosure of the relevant documents to the Belgian authorities would affect it in 'any demonstrable way'. ${ }^{81}$ Therefore, to be successful, any person challenging the Minister's decision to approve a letter of request from a foreign state, must have a demonstrable interest either at common law or in terms of section 38 of the Constitution. However, a person who fails to convince a court that he has standing on the basis of section 38 of the Constitution, will find it difficult to convince the court that he has standing at common law. The Constitutional Court held that the common law parameters on standing are 'more restrictive' compared to the section 38 parameters. ${ }^{82}$

The ICCMA is silent on whether a search warrant may be issued to obtain evidence on the basis of a letter of request sent to South Africa in terms of section 7. In Beheersmaatschappij Helling I NV and Others $v$ Magistrate, Cape Town, and Others, Dutch authorities requested evidence from South Africa for the purpose of investigating the commission of an alleged offence in The Netherlands. The magistrate, in accordance with section 7 of the ICCMA and sections 20 and 21 of the CPA (these sections will be outlined below), issued warrants for the police to search the applicants' premises and seize the relevant articles. The applicants argued that ' $[\mathrm{n}]$ othing is said in the Act [(the ICCMA)] about searches or seizures ... [meaning] that searches and seizures were not intended to be governed by the Act' ${ }^{83}$ The Court held that: ${ }^{84}$

[I]t does not necessarily follow from the fact that the Co-operation Act is silent on the subject of searches and seizures that the Legislature did not intend the Act to apply also to evidence obtained by those means. Sections 20 and 21 of the Criminal Procedure Act already provide machinery for the application for and issue of search warrants: it may well be that the Legislature considered that machinery to be adequate as it stood for use in conjunction with $\mathrm{s} 7$ of the Co-operation Act and was content to leave it so. There is no incompatibility between the relevant provisions of the two Acts, viz s 7 of the

79 Idem par 14.

$80 \mathrm{~S} 38$ of the Constitution provides that 'Anyone listed in this section has the right to approach a competent court, alleging that a right in the Bill of Rights has been infringed or threatened, and the court may grant appropriate relief, including a declaration of rights. The persons who may approach a court are - (a) anyone acting in their own interest; (b) anyone acting on behalf of another person who cannot act in their own name; (c) anyone acting as a member of, or in the interest of, a group or class of persons; (d) anyone acting in the public interest; and (e) an association acting in the interest of its members'.

81 Tulip Diamonds FZE v Minister of Justice and Constitutional Development and Others supra $\mathrm{n} 67$ at parr 40-44.

82 Idem par 45.

83 Beheersmaatschappij Helling I NV and Others $v$ Magistrate, Cape Town, and Others supra $n 14$ at 109.

84 Ibid. 
Co-operation Act, on the one hand, and ss 20 and 21 of the Criminal Procedure Act, on the other.

The above decision shows that although section 7 of the ICCMA, in particular, and the ICCMA in general, are silent on the issue of search and seizure for the purpose of giving effect to a foreign letter of request, a search and seizure warrant may be issued by a South African court if the magistrate is of the view that that is the best way to give effect to a foreign letter of request. However, the search and seizure warrant must comply with South African law for the evidence in question to be handed over to the requesting state. If a court upholds a challenge to the validity of the search and seizure warrant, the court can make an order that the seized evidence not be handed over to the authorities of the foreign state. $^{85}$

It is important that the request from the foreign state is as clear as possible regarding the kind of evidence being sought from South African authorities. In Tulip Diamonds FZE v Minister of Justice and Constitutional Development and Others one of the arguments before the Constitutional Court was that the request was 'overbroad and vague', in the sense that it 'fail[ed] to explain the offences of which [the company being investigated] is suspected, and the terms of the Request, such as "all relevant documents" and "all invoices and diamond transports", are overbroad' ${ }^{86}$ In rejecting this argument, the Court held that: ${ }^{87}$

The Request is sufficiently detailed with regard to the crimes allegedly committed by [the company being investigated], the factual background to the allegations and the purpose for which Belgian authorities seek documents from [the courier]. Moreover, Tulip's arguments about overbreadth are undercut by the fact that the Request and subpoena yielded only a total of 18 responsive documents. This is hardly a burdensome and unwieldy volume. It does not appear that [the courier] had any difficulty ascertaining which documents in its possession were responsive to the subpoena.

It is argued that if a request is not sufficiently detailed with regard to the relevant information, it could successfully be challenged on the basis that it is overbroad and vague. This is the spirit of the conclusion by the Constitutional Court highlighted above.

Section 7(5) provides that after the Minister's approval, the request in question should be forwarded 'to the magistrate within whose area of jurisdiction the witness resides'. Section $7(5)$ should be read with section 8 which provides that:

(1) The magistrate to whom a request has been forwarded in terms of section 7 (5) shall cause the person whose evidence is required, to be subpoenaed to appear before him or her to give evidence or to produce any book, document or object and upon the appearance of such person

85 Ibid

86 Tulip Diamonds FZE v Minister of Justice and Constitutional Development and 87 Ibid. 
the magistrate shall administer an oath to or accept an affirmation from him or her, and take the evidence of such person upon interrogatories or otherwise as requested, as if the said person was a witness in a magistrate's court in proceedings similar to those in connection with which his or her evidence is required: Provided that a person who from lack of knowledge arising from youth, defective education or other cause, is found to be unable to understand the nature and import of the oath or the affirmation, may be admitted to give evidence in the proceedings without taking the oath or making the affirmation: Provided further that such person shall, in lieu of the oath or affirmation, be admonished by the magistrate to speak the truth, the whole truth and nothing but the truth.

(2) A person referred to in subsection (1) shall be subpoenaed in the same manner as a person who is subpoenaed to appear as a witness in proceedings in a magistrate's court.

(3) Upon completion of the examination of the witness the magistrate taking the evidence shall transmit to the Director-General the record of the evidence certified by him or her to be correct, together with a certificate showing the amount of expenses and costs incurred in connection with the examination of the witness.

(4) If the services of an interpreter were used at the examination of the witness, the interpreter shall certify that he or she has translated truthfully and to the best of his or her ability, and such certificate shall accompany the documents transmitted by the magistrate to the DirectorGeneral.

If the request in question is forwarded to a magistrate in whose area of jurisdiction the witness does not reside, such magistrate does not have jurisdiction over the matter. This means, inter alia, that the witness cannot be prosecuted for failure to appear before that magistrate and that the evidence that such magistrate has elicited from a witness would have been obtained illegally. ${ }^{88}$ In Tulip Diamonds FZE $v$ Minister of Justice and Constitutional Development and Others the Constitutional Court was divided on, inter alia, the issue of whether the magistrate to whom the request had been forwarded was the right magistrate. The majority held that he was. ${ }^{89}$ What is important to note about this case is that failure to forward the request to the magistrate, in whose jurisdiction the witness resides, taints the process and the evidence gathered through the process. Whether or not a witness resides at a particular place will depend on the facts of the case.

For a subpoena issued on the basis of sections 7 and 8 to be valid, it must be issued by the magistrate in whose area of jurisdiction the witness resides As Jafta J held in Tulip Diamonds FZE v Minister of Justice and Constitutional Development and Others '[i]t is not any magistrate who has the power, but a magistrate of the area in which the witness resides'. ${ }^{90}$ It is also critical that the document indicating that a request

88 S 10 of the ICCMA makes it an offence for a witness who has been subpoenaed to fail to appear before a magistrate.

89 Tulip Diamonds FZE v Minister of Justice and Constitutional Development and Others supra $n 67$ at parr 47-48.

90 Idem par 107. 
was forwarded to the magistrate on the basis of section 7(5) should make it "clear that the request on which [the] magistrate ... acted was forwarded to him by the Director-General as required by s 7(5), or by someone else'. ${ }^{91}$ This is important, inter alia, for the person who is affected by the letter of request to determine whether or not the person who forwarded the request to the magistrate was clothed with such authority. If that person was not authorised to forward such request to the magistrate, he would have acted illegally and the action could be challenged successfully for flouting the principle of legality. It should be recalled, as the High Court stated in Freedom Under Law $v$ National Director of Public Prosecutions and Others, that a legality review... is concerned with the lawfulness of the exercise of public power. Decisions must be authorised by law and any statutory requirements or preconditions that attach to the exercise of the power must be complied with'. 92

Another important factor is the extent to which a magistrate can rely on other pieces of legislation to execute his or her duties under section 8 of the ICCMA. In Tulip Diamonds FZE $v$ Minister of Justice and Constitutional Development and Others, ${ }^{93}$ one of the issues before the Constitutional Court was whether the magistrate had acted legally by subpoenaing the witness on the basis of section 205 of the CPA. The magistrate issued a subpoena for the applicant's courier to appear before him and be examined, or to produce the relevant documents if he did not want to be examined. The subpoena was issued on the basis of section 205 of the $\mathrm{CPA}^{94}$ instead of section 8 of the ICCMA. The applicants argued, inter alia, that the subpoena had been issued unlawfully because it was based on section 205. The majority decision observed that '[i]t is clear that the magistrate deliberately and intentionally relied on s[ection] 205. This was no administrative error. However, the question that

91 Idem par 112.

92 Freedom Under Law $v$ National Director of Public Prosecutions and Others supra $\mathrm{n} 76$ at par 126.

93 Tulip Diamonds FZE v Minister of Justice and Constitutional Development and Others supra $\mathrm{n} 67$

94 S 205(1) of the CPA provides that 'A judge of a High Court, a regional court magistrate or a magistrate may ... upon the request of a Director of Public Prosecutions or a public prosecutor authorized thereto in writing by the Director of Public Prosecutions, require the attendance before him or her or any other judge, regional court magistrate or magistrate, for examination by the Director of Public Prosecutions or the public prosecutor authorized thereto in writing by the Director of Public Prosecutions, of any person who is likely to give material or relevant information as to any alleged offence, whether or not it is known by whom the offence was committed: Provided that if such person furnishes that information to the satisfaction of the Director of Public Prosecutions or public prosecutor concerned prior to the date on which he or she is required to appear before a judge, regional court magistrate or magistrate, he or she shall be under no further obligation to appear before a judge, regional court magistrate or magistrate'. 
remains to be answered is the effect of this reliance'. 95 The majority held that: 96

The empowering provision in this instance is s[ection] 8 of the Co-operation Act. This is the prism through which a magistrate's power to issue a subpoena in the context of mutual legal assistance must be viewed. Section 8(1) provides that a magistrate must ensure that a person whose evidence is required appear before him or her under oath. Section 8(2) describes the manner in which that person may be subpoenaed. The focus of this aspect of review proceedings must therefore be s[ection] 8(2). This section is not specific about exactly how a magistrate should issue the subpoena. It is silent as to the penalties of non-compliance with a subpoena. One is inclined to think there is an omission in the section. However, the section is specific in stating that such a person must be subpoenaed in the same manner as they would be subpoenaed to appear in a magistrates' court. Therefore this court must determine whether s[ection] 8 is sufficient to independently empower and enable a magistrate to exercise his or her power in issuing a subpoena.

Section 8 is not independently sufficient to allow magistrates to issue subpoenas in instances of mutual legal assistance. The language of s[ection] $8(2)$ is broad. It envisages magistrates using the ordinary mechanisms they employ when issuing subpoenas. Section 205 is such a mechanism. That these mechanisms were never engineered to be used in the general scheme of mutual legal assistance in terms of the Co-operation Act explains the inconsistencies that arise when these mechanisms are used to fulfil an objective in terms of the Co-operation Act. that: 97

However, the minority came to a different conclusion. They held

The process authorised by s[ection] 8 of the Co-operation Act is materially different from the one permitted by s[ection] 205 of the Criminal Procedure Act. Members of the National Prosecuting Authority play no role in a s[ection] 8 process. In fact the section does not refer to them at all. In a s[ection] 8 process the examination of the witness is conducted by the magistrate who takes the evidence. At the completion of the process the magistrate is obliged to submit to the Director-General a certified copy of the record. A person subpoenaed under s[ection] 8 must appear before the magistrate on the appointed date for the purpose of giving evidence. He or she cannot avoid appearing by submitting an affidavit. He or she has to take an oath or affirmation before the magistrate who takes the evidence which must be tendered orally. Therefore a process mandated by s[ection] 205 of the Criminal Procedure Act cannot be equated to the process authorised by s[ection] 8 of the Co-operation Act. The two processes are like chalk and cheese. Section 205 of the Criminal Procedure Act does not confer the power to take evidence in terms of a request submitted to a magistrate under s[ection] 7(5) of the Co-operation Act.

95 Tulip Diamonds FZE v Minister of Justice and Constitutional Development and Others supra $n 67$ at par 49.

96 Idem parr 50-51.

97 Idem parr 118-119. 
Another issue that has been dealt with is the relationship between section 7 of the ICCMA and sections 20 and 21 of the CPA. Section 20 of the CPA provides that:

The State may, in accordance with the provisions of this Chapter, seize anything - (a) which is concerned in or is on reasonable grounds believed to be concerned in the commission or suspected commission of an offence whether within the Republic or elsewhere; (b) which may afford evidence of the commission or suspected commission of an offence whether within the Republic or elsewhere; or (c) which is intended to be used or is on reasonable grounds believed to be intended to be used in the commission of an offence.

Section 21 provides that the articles referred to in section 21 may be seized on the basis of a search warrant issued by a magistrate or justice of the peace or by a judge or any judicial officer presiding at the proceedings. It is clear that section 7 of the ICCMA does not mention that the magistrate in question has the power to issue a search and seizure warrant. As mentioned above, the magistrate in Beheersmaatschappij Helling I NV and Others $v$ Magistrate, Cape Town, and Others held that section 7 of the ICCMA is not incompatible with sections 20 and 21 of the CPA. ${ }^{98}$

However, the search and seizure warrants must comply with South African law for them to be valid and for the evidence in question to be legally handed over to the authorities of a foreign country. For example, they should not be 'too vague and too broad'. 99 The Constitutional Court in Thint Holdings (Southern Africa) (Pty) Ltd and Another $v$ National Director of Public Prosecutions, Zuma $v$ National Director of Public Prosecutions 100 discussed, in detail, the requirements that have to be met for a search warrant to be valid. The above case law shows that there is nothing in the ICCMA which bars a magistrate from invoking a provision of another piece of legislation to implement the ICCMA. It is submitted that what, however, is critical is that in invoking another piece of legislation, as a tool to help give effect to any provision of the ICCMA, a magistrate should clearly explain why he or she decided to invoke the mechanism of that other piece of legislation instead of relying exclusively on the provisions of the ICCMA and the relevant regulations. If the ICCMA and the relevant regulations are unhelpful, then the magistrate is justified to invoke a procedure in another relevant piece of legislation. The reason behind taking such a decision should be explained fully.

98 Beheersmaatschappij Helling I NV and Others $v$ Magistrate, Cape Town, and Others supra $\mathrm{n} 14$ at 109

99 Idem at 116

100 Thint Holdings (Pty) Ltd $v$ National Director of Public Prosecutions and Others, Zuma and Another $v$ National Director of Public Prosecutions and Others 2008 (2) SACR 421 (CC); 2009 (1) SA 1 (CC). 


\section{Admissibility in South African Courts of Evidence Obtained from Abroad}

Section 5 of the ICCMA deals with the admissibility of evidence obtained from abroad based on a letter of request. It provides as follows:

(1) Evidence obtained by a letter of request shall be deemed to be evidence under oath if it appears that the witness was in terms of the law of the requested State properly warned to tell the truth.

(2) Evidence obtained by a letter of request prior to proceedings being instituted shall be admitted as evidence at any subsequent proceedings and shall form part of the record of such proceedings if - (a) each party against whom the evidence is to be adduced agrees to the admission thereof as evidence at such proceedings; or (b) the court, having regard to - (i) the nature of the proceedings; (ii) the nature of the evidence; (iii) the purpose for which the evidence is tendered; (iv) any prejudice to any party which the admission of such evidence might entail; and (v) any other factor which in the opinion of the court should be taken into account, is of the opinion that such evidence should be admitted in the interests of justice.

(3) The provisions of subsection (2) shall not render admissible any evidence which would be inadmissible, had such evidence been given at the subsequent proceedings by the witness from whom it was obtained.

(4) Evidence obtained by a letter of request after the institution of proceedings shall form part of the record of such proceedings and shall be admitted as evidence by the court or presiding officer which issued the letter of request in so far as it is not inadmissible at such proceedings.

At the admissibility stage, there is a difference between evidence obtained from abroad based on a letter of request issued after proceedings have been instituted (under section 2(1)) on the one hand, and evidence obtained from abroad prior to proceedings being instituted (under section 2(2)) on the other. For the evidence obtained from abroad prior to proceedings being instituted, one of the requirements in section $5(2)$ has to be complied with. A provision which is more or less similar to section 5(2) of the ICCMA appears in the Law of Evidence Amendment Act regulating the admissibility of hearsay evidence (section 3(1)). ${ }^{101}$ The author is not aware of any case in which a South African court has

101 S 3(1) of the Law of Evidence Amendment Act (No 45 of 1988) provides that 'Subject to the provisions of any other law, hearsay evidence shall not be admitted as evidence at criminal or civil proceedings unless (a) - each party against whom the evidence is to be adduced agrees to the admission thereof as evidence at such proceedings; (b) the person upon whose credibility the probative value of such evidence depends, himself testifies at such proceedings; or (c) the court, having regard to - (i) the nature of the proceedings; (ii) the nature of the evidence; (iii) the purpose for which the evidence is tendered; (iv) the probative value of the evidence; (v) the reason why the evidence is not given by the person upon whose credibility the probative value of such evidence depends; (vi) any prejudice to a party which the admission of such evidence might entail; and (vii) any other factor which should in the opinion of the court be taken into account, is of the opinion that such evidence should be admitted in the interests of 
interpreted section 5(2) of the ICCMA. However, there are cases where courts have referred to section 5(2). For example, in Thint Holdings (Southern Africa) (Pty) Ltd and Another $v$ National Director of Public Prosecutions, Zuma $v$ National Director of Public Prosecutions the Constitutional Court held that: ${ }^{102}$

[T] he admissibility of any documents obtained under section 2(2) at the criminal trial falls to be determined in the light of section 5(2) of the Act. That section regulates the approach the court must take in relation to admissibility. One of the factors to be taken into account is any prejudice to any party which the admission of such evidence might entail.

It is argued that the same principles that have been developed by South African courts on the relevant paragraphs of section 3(1) of the Law of Evidence Amendment Act, could be applied when interpreting section 5(2) of the ICCMA. For example, the Supreme Court of Appeal held that section 3(1)(c) of the Law of Evidence Amendment Act, which allows courts to admit hearsay evidence in the interests of justice, gives courts a wide discretion to admit hearsay evidence. ${ }^{103}$ In Giesecke and Devrient Southern Africa (Pty) Ltd $v$ Minister of Safety and Security the Supreme Court of Appeal held that: ${ }^{104}$

The section requires that the court should have regard to the collective and interrelated effect of all the considerations in paras (i) - (iv) [sic] of the section and any other factor that should, in the opinion of the court, be taken into account. The section thus introduces a high degree of flexibility to the admission of hearsay evidence with the ultimate goal of doing what the interests of justice require.

It is argued that section 5(2) of the ICCMA also introduces a high degree of flexibility to the admission of evidence, obtained by a letter of request prior to proceedings being instituted, at any subsequent proceedings with the ultimate goal of doing what the interests of justice require. There are two grounds upon which a court is allowed to admit evidence obtained by a letter of request prior to proceedings being instituted: One, if each party to the proceedings against whom the

justice'. One of the differences between s 5(2) of the ICCMA and s 3(1)(c) of the Law of Evidence Amendment Act is that the latter provides for seven factors that a court has to consider in deciding whether or not to admit the evidence in question and the former provides for five factors.

102 Thint Holdings (Southern Africa) (Pty) Ltd and Another v National Director of Public Prosecutions, Zuma v National Director of Public Prosecutions supra $\mathrm{n}$ 18 at par 45; see also The National Director of Public Prosecutions $v$ Jacob Gedleyihlekisa Zuma, Thint Holdings (Southern Africa) (Pty) Ltd and Thint (Pty) Ltd supra $\mathrm{n} 15$.

103 President of the RSA and Others $v$ Mail and Guardian Ltd 2011 (2) SA 1 (SCA) par 16.

104 Giesecke \& Devrient Southern Africa (Pty) Ltd $v$ Minister of Safety and Security 2012 (2) SA 137 (SCA) par 31; see also Jimmy Sebone Seemela $v$ S [2015] ZASCA 41 (2015-3-26) par 12 'For many years our law knew a rigid exclusionary rule which allowed specific exceptions but no relaxation. Now there is no exclusion as such. Hearsay evidence may now be accepted subject to the broad, almost limitless criteria set out in s 3(1).' 
evidence is to be adduced agrees to the admission of the evidence at such proceedings; or, two, if the court, after considering the factors outlined section 5(2)(b), is of the view that it is in the interests of justice to admit such evidence. It would appear that the general rule is that evidence obtained by a letter of request prior to proceedings being instituted is not admissible at the subsequent proceedings. Section 5(2)(b) creates exceptions to that general rule. The two exceptions are mutually exclusive: If the relevant parties agree that evidence should be admitted in terms of section 5(2)(a), the court does not have to invoke section $5(2)$ (b); if the relevant parties object to the admission of such evidence, then the court has the discretion to invoke section 5(2)(b).

Evidence obtained from abroad is not automatically admissible in South Africa. Its admissibility could still be challenged by the accused. This is evident from sections 5(3) and (4) of the ICCMA and, of course, section 35(3)(i) of the Constitution which provides that an accused has the right 'to adduce and challenge evidence'. In Thint Holdings (Southern Africa) (Pty) Ltd and Another $v$ National Director of Public Prosecutions, Zuma $v$ National Director of Public Prosecutions the applicants argued that: ${ }^{105}$

[A] though the right to cross-examine is a fundamental right, under section 2(2) a person who is subsequently accused has no right to challenge and adduce evidence by means of cross-examination of a witness from abroad. An accused ... can only challenge under section 5(2) of the Act the admissibility of evidence already taken.

The Court held that: ${ }^{106}$

The trial court will still need to determine the relevance, admissibility and cogency [of the documents obtained from abroad]. It is then and there that the applicants will have the full opportunity to engage with the prosecution and challenge the admissibility of the evidence. Of particular importance ... is that under section 5(2)(b) of the Act and in terms of the Constitution, in particular subsections 35(3) and 35(5), the trial court will surely ensure that the fair trial rights of the applicants are protected.

In the author's view, the court did not directly address the applicants' concern. The issue was not whether the applicants would have the opportunity to challenge the admissibility of the evidence in question or not. The applicants knew that they could indeed challenge the admissibility of such evidence on the basis of section 5(2) of the ICCMA. Their concern was that the accused would not have had the opportunity to cross-examine the witness in question. Practically, this evidence amounts to hearsay evidence. However, the South African Constitution does not confer on an accused an express right to cross-examine state witnesses. Section 35(3)(i) provides that the accused has the right to

105 Thint Holdings (Southern Africa) (Pty) Ltd and Another $v$ National Director of Public Prosecutions, Zuma v National Director of Public Prosecutions supra $n$ 18 at par 57

106 Idem par 58. 
adduce and challenge evidence. Section 35(3)(i) has been interpreted by the courts as conferring on the accused the right to cross-examine state witnesses. ${ }^{107}$ Furthermore, an investigation in terms of section 2(2) of the ICCMA is carried out before the person in question becomes an accused. He could be a suspect, an arrested person or a detained person but that does not mean that he has the right to cross-examine witnesses. Sections 35(1) and (2) of the South African Constitution do not confer on an arrested person a right to challenge evidence. This right is only available to an accused person. Section 30 of the ICCMA provides that:

Any deposition, affidavit, record of any conviction or any document evidencing any order of a court, issued in a foreign State, or any copy or sworn translation thereof, may be received in evidence at any proceedings in terms of a provision of this Act if it is - (a) authenticated in the manner in which foreign documents are authenticated to enable them to be produced in any court in the Republic; or (b) authenticated in the manner provided for in any agreement with the foreign State concerned.

Section 30 seems to be straight-forward but what is not clear is the extent to which a 'record of any conviction' of a court in a foreign state could be put to use by a South African court. Such a record could be used, for example, at sentencing as an aggravating factor by showing that the accused has a previous conviction. ${ }^{88}$

107 In S v Msimango and Another 2010 (1) SACR 544 (GSJ) it was held that (par 27 ) 'the right of an accused person to adduce and challenge evidence as enshrined in s 35(3)(i) of the Constitution, undoubtedly includes the right to cross-examination... [T] here was overwhelming and persuasive authority for this proposition... [T] he fact that s 35(3)(i) of the Constitution does not expressly or implicitly refer to cross-examination, to exclude such right would amount to a too narrow and simplistic interpretation of the section'; see also Sv Ngudu 2008(1) SACR 71(N) par 24.

108 S 271 of the CPA provides that "(1) The prosecution may, after an accused has been convicted but before sentence has been imposed upon him, produce to the court for admission or denial by the accused a record of previous convictions alleged against the accused. (2) The court shall ask the accused whether he admits or denies any previous conviction referred to in subsection (1). (3) If the accused denies such previous conviction, the prosecution may tender evidence that the accused was so previously convicted. (4) If the accused admits such previous conviction or such previous conviction is proved against the accused, the court shall take such conviction into account when imposing any sentence in respect of the offence of which the accused has been convicted'. See also s 272 which allows a prosecutor to adduce evidence of a previous conviction in a foreign state. For a discussion of the issue of the recognition of foreign conviction in South Africa, see Mujuzi 'Legal Pluralism and Using Foreign Previous Convictions or Criminal Records For The Purpose Of Sentencing: Implementing Article 41 of the United Nations Convention against Corruption in South Africa' 2014 The Journal of Legal Pluralism and Unofficial Law 338-356. 


\section{Illegally Obtained Evidence for Use in a Foreign State}

Evidence which has been obtained on the basis of the ICCMA has to be obtained legally otherwise the process that was followed to obtain it will be challenged successfully before a court of law. For example, if the evidence was obtained on the basis of a search and seizure warrant, such warrant must have been issued and executed legally. As mentioned earlier, a search warrant, in terms of South African law, has to meet certain requirements for it to be valid. One issue that has to be examined relates to which remedy is at the disposal of a person who is being investigated in a foreign country when evidence, which was transferred to such country, was obtained unlawfully in South Africa? This issue arose in Beheersmaatschappij Helling I NV and Others $v$ Magistrate, Cape Town, and Others. In this case, the High Court found that the search and seizure warrants that had been issued by a magistrate to gather evidence that had been requested by the Dutch authorities were invalid for being too vague and too broad. The Court also held that the evidence in question had been gathered illegally. ${ }^{109}$ Because the evidence in question had already been sent to the Dutch authorities, the South African authorities argued that 'the matter was moot and academic inasmuch as the electronic data and copies of the documents which they sought had already been handed over to the Dutch authorities, and there was no order which this Court could make to undo that'. ${ }^{10}$ The Court held that there was evidence that the application before it 'may well have an influence on the' proceedings that were pending in The Netherlands against the applicants. ${ }^{111}$ It is against that background that the Court relied on the jurisprudence of the Constitutional Court, ${ }^{12}$ and held that the relief sought by the applicants was not moot. ${ }^{113}$ However, unlike in Mohamed and Another $v$ President of the Republic of South Africa and Others ${ }^{114}$ where the Constitutional Court expressly ordered that its

109 Beheersmaatschappij Helling I NV and Others $v$ Magistrate, Cape Town, and Others supra $\mathrm{n} 14$ at 116 .

110 Idem at 118.

111 Ibid.

112 Mohamed and Another $v$ President of the Republic of South Africa and Others 2001 (3) SA 893 (CC). In this case, the South African authorities had surrendered the applicant to the USA where he was prosecuted for terrorism which offence attracted the death penalty, without obtaining assurances from the USA that the applicant would not be sentenced to death or, if sentenced to death, that the death sentence would not be executed, even though the death penalty has been found to be unconstitutional in South Africa.

113 Beheersmaatschappij Helling I NV and Others v Magistrate, Cape Town, and Others supra n 14 at 119.

114 Mohamed and Another $v$ President of the Republic of South Africa and Others supra $\mathrm{n} 112$. 
judgement should be brought to the attention of the relevant court in the USA, ${ }^{115}$ in this case the Court did not make an express order that its judgement should be brought to the attention of the Dutch court. In this case there was evidence that the Dutch court was waiting for the outcome of the application before deciding whether or not to use the evidence in question. What emerges from this case, is that there is a danger that evidence from another country may be obtained in a manner that violates the laws of that country. For the victim of such violations to prevent the evidence from being used in a foreign country, he should challenge, in the courts of the country from where evidence has been obtained, the validity of the process that was followed to obtain it. Failure to do so means that that evidence may be admitted in a foreign country. However, courts in the country to which that evidence has been sent should be willing to respect the decisions of the courts in the countries from which that evidence has originated. The test to be used is not whether the evidence was gathered in a manner that would have complied with the laws of the country to which it has been transferred. The question should be whether the evidence was gathered in a manner that complied with the laws of the country from which it has originated. This would discourage law enforcement officers from disregarding the laws of other countries in the process of gathering evidence.

\section{Human Rights in the Context of the ICCMA}

The transfer of evidence from one country to another will almost always involve human rights. This is inevitable in the light of the fact that two different legal systems could provide for different laws and procedures that have to be followed to gather evidence. When these systems meet at some point, tension is sometimes inevitable. In the event that something goes wrong in the process, it will be necessary to address human rights. The ICCMA provides for some rights and privileges of witnesses. Section 9 provides that:

(1) In respect of the giving of evidence or the production of any book, document or object at an examination in terms of section 8 , the law relating to privilege as applicable to a witness giving evidence or subpoenaed to produce a book, document or object in a magistrate's court in similar proceedings, shall apply.

(2) Where a witness at such an examination claims privilege on the ground that he or she could not have been compelled to give the particular evidence in criminal proceedings in the requesting State, the magistrate shall record the witness' objection and may postpone the proceedings in order to obtain from a competent authority in the requesting State an intimation as to whether or not the witness could in criminal proceedings in the requesting State be compelled to give the evidence in question.

115 The Constitutional Court ordered that " $\mathrm{t}] \mathrm{h}$ he Director of this Court is authorised and directed to cause the full text of this judgment to be drawn to the attention of and to be delivered to the Director or equivalent administrative head of the Federal Court for the Southern District of New York as a matter of urgency'. 
(3) Where a witness' claim to privilege is not recognised by a competent authority in the requesting State the magistrate shall reject his or her objection and proceed to take the evidence.

(4) Any person required to give evidence at an examination under section 8 shall be entitled to payment of such expenses and fees as are payable to witnesses in a magistrate's court in proceedings similar to those in connection with which his or her evidence is required.

In interpreting and applying section 9(1), it should be recalled that the South African law of evidence provides for different privileges that a witness can invoke to refuse to give evidence. These include state and private privileges. ${ }^{116}$ One such privilege is legal professional privilege. Legal professional privilege is fundamental to the realisation of the right to a fair trial. In Thint (Pty) Ltd and Another $v$ National Director of Public Prosecutions and Others, Zuma and Another $v$ National Director of Public Prosecutions and Others the Constitutional Court held that the right to have privileged communications with a lawyer protected is necessary to uphold the right to a fair trial'. ${ }^{117}$ Therefore, a lawyer who has been subpoenaed to give evidence may invoke legal professional privilege and decline to give such evidence. However, a person who is subpoenaed to give evidence on the basis of section 8 of the ICCMA cannot refuse to give evidence because of the fact that the evidence in question could be used at his pending trial, either in South Africa or in the requesting country (should he be extradited to that country). Such a person may also not invoke his right to not incriminate himself as the reason for not giving evidence on the basis of section 8 of the ICCMA. If the evidence he has given at the section 8 examination is used at his subsequent trial, he has the right to challenge its admissibility in terms of section 35(5) of the Constitution. ${ }^{118}$ In terms of section $35(5)$ of the Constitution, a court must exclude evidence obtained in a manner that violates any right in the Bill of Rights if the admission of that evidence would render the trial unfair or otherwise be detrimental to the administration of justice. ${ }^{119} \mathrm{~A}$ person's right to human dignity is not violated simply because a court has accepted an application for a letter of request to be issued in terms of section 2(2) of the ICCMA. The Constitutional Court has held that ' $[\mathrm{t}] \mathrm{he}$ right to dignity however, does not necessarily extend to the right not to

116 Schwikkard \& Van der Merwe Principles of Evidence (2010) 123-178; Zeffertt \& Paizes The South African Law of Evidence (2009) 573-708.

117 Thint (Pty) Ltd and Another $v$ National Director of Public Prosecutions and Others, Zuma and Another $v$ National Director of Public Prosecutions and Others supra $\mathrm{n} 100$ at par 184.

118 Thatcher $v$ Minister of Justice and Constitutional Development and Others supra $\mathrm{n} 62$ at parr 83-94. S 35(5) of the Constitution provides that: 'Evidence obtained in a manner that violates any right in the Bill of Rights must be excluded if the admission of the evidence would render the trial unfair or otherwise be detrimental to the administration of justice'.

119 For a detailed discussion of case law from South African courts interpreting section 35(5) see Schwikkard \& Van der Merwe 181-266; Zeffertt \& Paizes $711-775$. 
be named as a suspect, once there is a reasonable suspicion that a crime has been committed'. 120

Section 9(2) deals with the issue of competence and compellability of witnesses. In the South African law of evidence, the general rule is that everyone is a competent and compellable witness. ${ }^{12}{ }^{1}$ In $S v$ Dladla, the High Court held that "everyone is presumed to be a competent and compellable witness' ${ }^{122}$ In the same case, the Court drew a distinction between a competent witness, on the one hand, and a compellable witness, on the other: 'A witness is competent if he or she may lawfully give evidence. A compellable witness is one who is competent and in addition can be forced to testify under the pain of punishment in terms of section 189 [of the CPA]'. ${ }^{23}$ In some countries, a spouse of the accused is a competent but not compellable witness for the prosecution. ${ }^{124}$ Therefore, if the evidence being sought from South Africa is for the purpose of prosecuting that person's spouse, he/she can invoke section $9(2)$ to refuse to give evidence. A witness who is subpoenaed to give evidence is entitled to payment of expenses and fees incurred to enable him to appear before the court to give evidence. ${ }^{125}$

Section 12 of the ICCMA provides that:

No witness residing in a foreign State and who attends a court or tribunal in the Republic shall, while so attending, be liable to be arrested in the Republic on any civil warrant for debt or on a criminal charge for the commission of an offence incurred or allegedly committed in the Republic, before his or her arrival in the Republic for the purpose of his or her attendance of such court or tribunal.

It is submitted that the rationale behind section 12 is to encourage people, who would otherwise not have come to South Africa to give evidence, to come to South Africa and give evidence without fear of being arrested. However, some witnesses seem to have not taken advantage of

120 Thint Holdings (Southern Africa) (Pty) Ltd and Another $v$ National Director of Public Prosecutions, Zuma v National Director of Public Prosecutions supra $n$ 18 at par 50.

121 S 192 of the CPA provides that '[e]very person not expressly excluded by this Act from giving evidence shall, subject to the provisions of section 206 , be competent and compellable to give evidence in criminal proceedings'.

122 S v Dladla 2011(1) SACR 80 (KZP) par 10

123 Ibid.

124 See, for example, s 217 of the Botswana Criminal Procedure and Evidence Act; $R v$ Mathaba [1989] LSCA 51 (on the position in Lesotho); Nalungwana and Another $v$ People (S.C.Z. Judgment No. 7 of 1986) [1986] ZMSC 6 (25 February 1986); (1986) Z.R. 28 (S.C.) (for the position in Zambia); $R v$ Hallett [2013] NZHC 1076 (14 May 2013) (for the position in New Zealand) and Sesawo s/o Kermesi $v$ Uganda [1978] UGCA 3 (on the position in Uganda).

125 Ss $9(4) \& 11(2)$ 
section $12 .{ }^{126}$ For the witness to benefit from the protection offered under section 12 , such witness has to be residing in a foreign country. The ICCMA does not define what it means to be residing in a foreign country. Case law on this issue will be helpful. In Mayne $v$ Main ${ }^{127}$ the Supreme Court of Appeal held that: ${ }^{128}$

$[O]$ ne needs ... to adopt a common sense and realistic approach when deciding whether, having regard to all the relevant circumstances, a person can be said to be residing at a particular place ... This is all the more so because of modern day conditions and attitudes and the tendency towards a more itinerant lifestyle, particularly amongst business people ... Not to do so might allow certain persons habitually to avoid the jurisdictional nets of the courts and thereby escape legal accountability for their wrongful actions.

The Court added that 'there can be no quibble' with the argument that 'residence connotes some acceptable degree of permanence and stability'. ${ }^{129}$ Therefore, in determining whether or not the witness in question benefits from the section 12 protection, the above holding by the Supreme Court of Appeal is useful. The seriousness or otherwise of the offence does not matter. This means that even if there is a warrant for that person's arrest for offences such as rape, murder, treason, drug trafficking, and torture - provided that the warrant was issued by South African authorities - it would be illegal for such person to be arrested in South Africa. It is argued that if there is a warrant of arrest for that person from Interpol, for instance, or from another country for an offence committed outside South Africa, South Africa can lawfully execute that warrant and have that person arrested notwithstanding section 12 . This is because the offence for which the person is being arrested was not allegedly committed in South Africa. If such a person commits an offence after his arrival in South Africa, he does not enjoy the protection offered by section 12 . If he has been arrested for an offence committed after his arrival to give evidence in South Africa, he cannot be prosecuted for the offence for which he would not have been arrested on the basis of section 12.

Section 3 of the ICCMA provides that:

(1) Where a letter of request has been issued in terms of section 2(1), any party to such proceedings may, provided that it is permitted by the law of the requested State - (a) submit interrogatories which the court or presiding officer issuing the letter of request may attach to the letter of request; or (b) appear at the examination, either through a legal representative or, in the case of an accused who is not in custody or in

126 In $S v$ Basson supra $\mathrm{n} 37$ at 194, it is stated that the witness in question had been in South Africa and questioned by South African authorities before he went back to the USA. When he was called by the prosecution to come back to South Africa and give evidence at the accused's trial, he refused. A letter of request had to be issued for his evidence to be obtained on the basis of $\mathrm{s}$ 2(1).

127 Mayne v Main [2001] 3 All SA 157 (A).

128 Idem par 6.

129 Idem par 7. 
the case of a private prosecutor, in person, and may examine, crossexamine and re-examine the witness.

(2) Where a letter of request has been issued in terms of section 2(2), the person in charge of the investigation relating to the alleged offence may, provided that it is permitted by the law of the requested State - (a) submit interrogatories which the judge or magistrate issuing the letter of request may attach to the letter of request; or (b) appear at the examination and question the person concerned.

(3)(a) Where proceedings have been instituted and the application for a letter of request is made by the State the court or presiding officer may as a condition of the letter of request order that the costs of legal representation for the accused be paid by the State.

(b) Notwithstanding the fact that a presiding officer has made an order contemplated in paragraph (a), he or she may, if he or she is of the opinion that a refusal by the accused to admit the evidence obtained by means of the letter of request is unreasonable and unjustifiable, at the conclusion of the proceedings make such order against the accused as to the costs of sending the letter of request and all proceedings to give effect thereto as he or she may reasonably deem appropriate.

Sections 3(1)(a) and (b) give parties to the proceedings an opportunity to ask the relevant questions of a witness in a foreign state. In terms of section $3(1)(b)$, any party to the proceedings is allowed to examine, cross-examine and re-examine the witness. Section 3(3)(b) appears to be problematic in that it could be used to threaten the accused's constitutional right to challenge evidence which is guaranteed under section 35(3)(i) of the Constitution. It should be recalled that the right to adduce and challenge evidence is one of the non-derogable rights in the South African Constitution. ${ }^{130}$ Section 3(3)(b) gives the presiding officer a discretion to impose what could be a heavy financial burden on the accused if he is of the view that the accused's refusal to admit the evidence in question was unreasonable and unjustifiable. The accused, because of the danger of conviction, should have the opportunity to challenge any evidence on any ground without fear of incurring financial penalties for challenging such evidence. If the presiding officer comes to the conclusion that the accused's submissions are unfounded, he should reject them and admit the evidence in question without making an order for the accused to reimburse the state for gathering the evidence that was used at the accused's prosecution. Even if the accused was represented by a lawyer at the examination of a witness in a foreign country, that, in itself, should not be invoked as a ground to hold that his opposition to the admission of evidence was unreasonable or unjustified.

Whether or not a person, who runs the risk of being prosecuted on the basis of the evidence being sought in terms of the ICCMA, has the right to challenge the validity of the search warrants issued in terms of section $2(2)$ is still unsettled. In Thint (Pty) Ltd $v$ National Director of Public Prosecutions and Others the Supreme Court of Appeal held that 'a person who is at risk of prosecution if a warrant for search and seizure is

130 See Constitution of the Republic of South Africa 1996 (Table of NonDerogable Rights). 
executed has standing to challenge the validity of the warrant for that reason alone. That being so it also cannot afford him or her standing to challenge the validity of a letter requesting that such a warrant be issued'. 131

However, on appeal the Constitutional Court held that: ${ }^{132}$

The Supreme Court of Appeal concluded that the applicants did not have standing to challenge the issue of the letter of request. It concluded that the process of obtaining information is a preliminary process that does not affect the rights of the applicant. In our view, this is a matter that does not need to be decided in this case and we accordingly refrain from doing so. We should note, however, that our Constitution has adopted a broad approach to questions of standing. We wish to make it clear that we are not persuaded that the approach of the Supreme Court of Appeal is necessarily correct given our constitutional approach to standing and we leave this question open for consideration in another case.

In Mudaly $v$ Gwala and Others, in which the applicant challenged the validity of two search and seizure warrants on the basis that he ran the risk of prosecution, the High Court referred to the above two decisions and observed that " $\mathrm{t}]$ he superior courts are divided as to whether a person has standing to challenge the validity of a search and seizure warrant, merely because he or she risks prosecution'. ${ }^{133}$ The High Court followed the Constitutional Court's reasoning. ${ }^{134}$ In Reuters Group PLC and Others $v$ Viljoen $N O$ and Others, ${ }^{135}$ the prosecutors promised the applicants that they would not request the United Kingdom authorities for assistance to force the applicants to hand over video footage that was needed for the purpose of prosecuting murder suspects, but went ahead and invoked section 31 of the ICCMA and requested the United Kingdom authorities to acquire the necessary evidence from the applicants. The Court held that the prosecutor's conduct was unconstitutional, inter alia, for not giving the applicants the opportunity to be heard before they requested the United Kingdom authorities to assist them in obtaining the video footage. This is due to the fact that the applicants had a legitimate expectation that they would be informed.

\section{Conclusion}

This article has highlighted the issues that South African courts have dealt with in implementing some of the sections of the ICCMA - those sections

131 Thint (Pty) Ltd $v$ National Director of Public Prosecutions and Others supra $n$ 17 at par 19

132 Thint Holdings (Southern Africa) (Pty) Ltd and Another $v$ National Director of Public Prosecutions, Zuma v National Director of Public Prosecutions supra $\mathrm{n}$ 18 at par 47.

133 Mudaly v Gwala and Others 2011 (1) SACR 302 (KZD) par 2. This case was not concerned with the ICCMA.

134 Mudaly $v$ Gwala and Others supra $\mathrm{n} 133$ at par 20.

135 Reuters Group PLC and Others v Viljoen NO and Others 2001 (2) SACR 519 (C). 
that are relevant to obtaining and admitting evidence. In particular, it dealt with how 'evidence' is defined in the ICCMA and how courts have applied that definition; the circumstances in which South African courts have issued letters of request to other countries and the conditions that have to be met for such letters to be issued; the meaning of the term 'interests of justice' as one of the factors that have to be in place before South African courts issue a letter of request; the procedure that has to be followed in dealing with letters of request from foreign countries; the admissibility of evidence, in South African courts, obtained from abroad on the basis of letters of request; the question of whether evidence obtained from South Africa illegally may be used in a foreign country; and human rights in the context of the ICCMA. It is recommended that section 7 of the ICCMA should be amended to be framed in the same manner as section 7 of the Namibian ICCMA ${ }^{136}$ for the reasons given below. There are several differences between section 7 of the ICCMA and section 7 of the Namibian ICCMA. Section 7 of the Namibian ICCMA provides that:

(1) A request by a court or tribunal of competent jurisdiction in a foreign State, or by an appropriate government body in a foreign State, for assistance in obtaining evidence in Namibia for use in that State shall be submitted to the Permanent Secretary or, in a case of urgency, directly to the magistrate's court within whose area of jurisdiction the person whose evidence is required resides or is.

(2) When a request from a foreign State for assistance in obtaining evidence in Namibia is in terms of subsection (1) received - (a) by the Permanent Secretary shall forward such request to the magistrate's court within whose area of jurisdiction the person whose evidence is required resides or is; (b) by such a magistrate's court, the Permanent Secretary shall without delay be notified thereof in writing by the clerk of the court and be furnished with a certified copy of such a request.

(3) Upon receipt of by a magistrate's court of a request contemplated in subsection (1), that court shall satisfy itself - (a) that the proceedings have been instituted in a criminal court or tribunal of competent jurisdiction in the requesting state concerned; or (b) that - (i) there are reasonable grounds for believing that an offence has been committed in that requesting state or that it is necessary to determine whether an offence has been committed; and (ii) an investigation in respect of thereof is being conducted in that requesting State.

(4) For the purposes of subsection (3), a court may rely on a certificate purporting to be issued by any competent authority of the requesting State concerned, stating the facts contemplated in paragraph (a) or (b) of that subsection.

The differences between the two provisions are as follows. First, in the ICCMA, a request must be sent to the Director-General. In the Namibian ICCMA, a request shall be submitted to the Permanent Secretary, except that in a case of urgency, the request may be sent directly to the magistrate's court within whose area of jurisdiction the person, whose evidence is required, resides or is. The Namibian ICCMA is thus more

136 International Co-operation in Criminal Matters Act No 9 of 2000. 
flexible and accommodating of urgent situations. Secondly, unlike in the South African legislation where the Director-General is required to satisfy him or herself that one of the conditions in section 7 (2) have been met, in the Namibian legislation, the Permanent Secretary's role is to forward the request to the magistrate in whose area of jurisdiction the witness resides or is, and it is the magistrate court's duty to satisfy itself that the requirements of section $7(3)$ have been complied with. This is an important distinction as the question of whether or not the requirements in section 7(3) of the Namibian ICCMA have been met is answered by a judicial officer as opposed to a member of the executive in South Africa. In Namibia, unlike in South Africa, policy and political considerations have a very limited, if any, role to play in deciding whether or not to afford assistance to a foreign country on the basis of section 7 . Thirdly, under section 7 of the ICCMA, a request can only be forwarded to the magistrate in whose area of jurisdiction the witness 'resides'. However, under section 7 of the Namibian ICCMA, a request is forwarded or sent to a magistrate in whose area of jurisdiction the witness 'resides or is'. The distinction between where a person 'resides' and where a person 'is', is critical because, residency connotes some degree of permanency or stability. On the other hand, if a person 'is' in a given area it does not mean that he is permanently situated there. 